\title{
An interesting case of predominantly sinistral population of Lymnaea stagnalis (L.) (Gastropoda: Pulmonata: Lymnaeidae)
}

\author{
MAXIM V. VINARSKI \\ Museum of Siberian Water Molluscs, Omsk State Pedagogical University, 14 Tukhachevskogo Emb., Omsk, Russian Federation, e-mail \\ radix@omskcity.com
}

VINARSKI M.V., 2007: An interesting case of predominantly sinistral population of Lymnaea stagnalis (L.) (Gastropoda: Pulmonata: Lymnaeidae). - Malacologica Bohemoslovaca, 6: 17-21. Online serial at $<$ http://mollusca.sav.sk> 20-March-2007.

\begin{abstract}
An interesting population of the common pond snail (L. stagnalis s.lat.) with a predominance of sinistral individuals is described. The discussion is based on a shell sample gathered by Russian malacologists Lindholm \& Bäckmann in July 1917 in vicinity of Sankt-Petersburg (housed in the Zoological Institute of the Russian Academy of Science). Shell measurements, their ratios as well as possible explanations for the origin of this dimorphism are given.
\end{abstract}

Key words: Lymnaea, sinistrality, shell coiling inversions, population genetics

\section{Introduction}

The phenomenon of inversion of shell chirality in freshwater and terrestrial snails, has intrigued malacologists for a long time. Within pulmonates it has been observed in at least 13 genera over eight superfamilies (ASAMI et al. 1998). Most of snail species are either entirely dextral or entirely sinistral, but intraspecific dimorphism for direction of shell coiling (i.e. co-occurrence of two chiral morphs) has evolved repeatedly within Gastropoda (e.g. GITTENBERGER 1988, ASAMI et al. 1998, reviewed in SCHILTHUIZEN \& DAVISON 2005). The coiling dimorphism has certain implications for genetics and evolutionary biology. In particular, the possibility of sympatric speciation by "left-right reversal" of coiling direction has repeatedly been discussed in the literature (ALEKSANDROV \& SERGIEVSKY 1979, JOHNSON 1982, GITTENBERGER 1988, ANISTRATENKO \& BAIDASHNIKOV 1991, UESHIMA \& ASAMI 2003). Perhaps, coil dimoprhism may represent the first known example of 'single-gene' speciation (GITTENBERGER 1988, UESHIMA and ASAMI 2003, but see JOHNSON et al. 1990; DAVISON et al. 2005).

Presumed adaptive consequences of chirality inversion in snails were considered by VERMEIJ (1975), GOULD et al. (1985), JOHNSON (1987) and INODA et al. (2003). Freshwater snails of the family Lymnaeidae Rafinesque, 1815 present a classical object of genetic studies of chirality inversion in molluscs. STURTEVANT
(1923), BOyCOTT \& Diver (1923) and BOyCOTT et al (1930), and subsequent geneticists (DIVER \& ANDERSON-KoTTÖ 1938, FREEMAN \& LUNDELIUS 1982), have investigated the coil inversion in Lymnaea peregra (O.F. Müller, 1774), and described the phenomenon as a case of "maternal inheritance", i.e. determination of shell chirality by the maternal nuclear genotype at a single locus (STURTEVANT 1923, UESHIMA \& ASAMI 2003). Sinistral lymnaeids occur very seldom in natural populations as these appear as a result of an occasional mutation among individuals with dextral shells (KHOKHUTKIN 1997, KRUGLOV 2005). Indeed, during my decennial (1996-2006) field sampling of lymnaeid snails in different regions of the Urals, Kazakhstan and Siberia I failed to find sinistral shell of Lymnaea although there are populations of $L$. peregra in France and Britain in which the portion of sinistral shells may reach 1-2\% (FREEMAN \& LUNDELIUS 1982).

Therefore I was surprised to find a large sample of sinistral Lymnaea shells in the W.A. Lindholm's malacological collection that is housed in the Zoological Institute of the Russian Academy of Science (SanktPetersburg; ZIN hereafter). This note describes this sample with discussion of possible ways of its origin.

\section{Material and methods}

The sample was collected by the prominent Russian malacologist Wasily (Wilhelm) Adolfovitch Lindholm 
(1874-1935) with assistance of a certain Bäckmann (a person not known among Russian malacologists of the first half of 20th) in July 1917 in the Ploskoje Lake in vicinity of Preobrazhenskoje (situated in the Luga District, currently Leningrad Region of Russia). It includes 34 empty shells (three of them were juvenile), many of which possess broken apices. All intact shells (14 specimens in total) were measured using calipers following a standard scheme of measurements (GLÖER 2002, KRUGLOV 2005). The number of whorls was counted to the nearest $1 / 8$.

Lindholm has identified these shells as belonging to Lymnaea stagnalis var. sinistrorsa Jeffreys. Following the recent taxonomy that does not accept any varieties within L. stagnalis (see GLÖER 2002), it would be designated here as L. stagnalis s.lat. It is worthy to remember, however, that KRUGLOV \& STAROBOGATOV (1985) have showed L. stagnalis s.lat. is a complex species including at least two reproductively isolated species, L. stagnalis s.str. and L. fragilis (L., 1758) (see also MEIER-BROOK 1993). Taking into consideration shell characters, these specimens would be identified as belonging to $L$. fragilis, however it is unverifiable due to absence of fixed soft body.

\section{Results and discussion}

The shells of sinistral Lymnaea stagnalis (Figs 1 and 2) are very similar to dextral shells of this species apart from different coiling direction. Their linear dimensions and conchological ratios calculated from the latter do not differ visible from linear dimensions and ratios of typical dextral L. stagnalis though $L$. stagnalis from the Ploskoje Lake may be sometimes smaller than their conspecifics from other areas. For instance, STADNICHENKO (2004) stated that L. stagnalis shells in Ukrainian populations may reach $56 \mathrm{~mm}$ heigth. In Western Siberia, the largest recorded specimen of this species was $56.5 \mathrm{~mm}$ (VINARSKI et al. 2007).
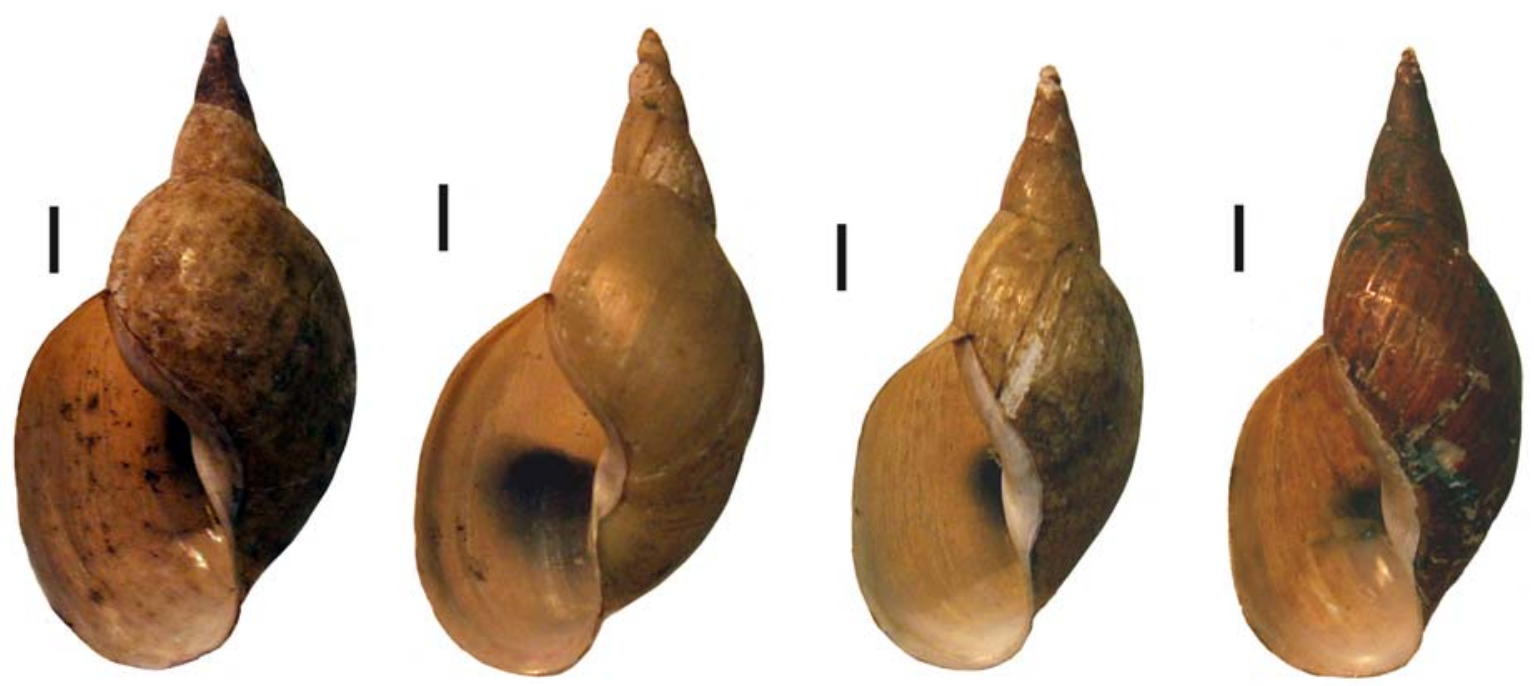

Fig. 1. The largest sinistral shells of L. stagnalis from the Ploskoje Lake. Scale bars $5 \mathrm{~mm}$.

In the catalogue of the ZIN malacological collection I found an indication that there is another sample of shells from the same habitat collected by Lindholm and Bäckmann at the same time. As appears from catalogue information, this sample includes eight dextral specimens determined by Lindholm as typical L. stagnalis. Unfortunately, I was not able to find this sample in the ZIN collection. However, the sinistral:dextral shells ratio of $35: 8$ is remarkable since dimorphic populations of pulmonate snails with obvious predominance of sinistral individuals seem very rare (GITTENBERGER 1988). The origin of the predominance of sinistral specimens in the Ploskoje Lake population of L. stagnalis may possibly be explained by "founder effect" (MAYR 1963). The principles of the maternal inheritance (STURTEVANT 1923, FREEMAN \& LUNDELIUS 1982) assume that all of the offspring of a given female are either dextral or sinistral (STURTEVANT 1923, GITTENBERGER 1988) and that even phenotypically dextral individual may produce wholly sinistral offspring and vice versa. At the same time, phenotypically (and genetically) dextral individuals may stem from a single ancestor having a sinistral genotype. Similarly, BOYCOTT \& DIVER (1930) when rearing sinistral $L$. peregra, reported sinistral stocks in which rare dextral snails appeared. 


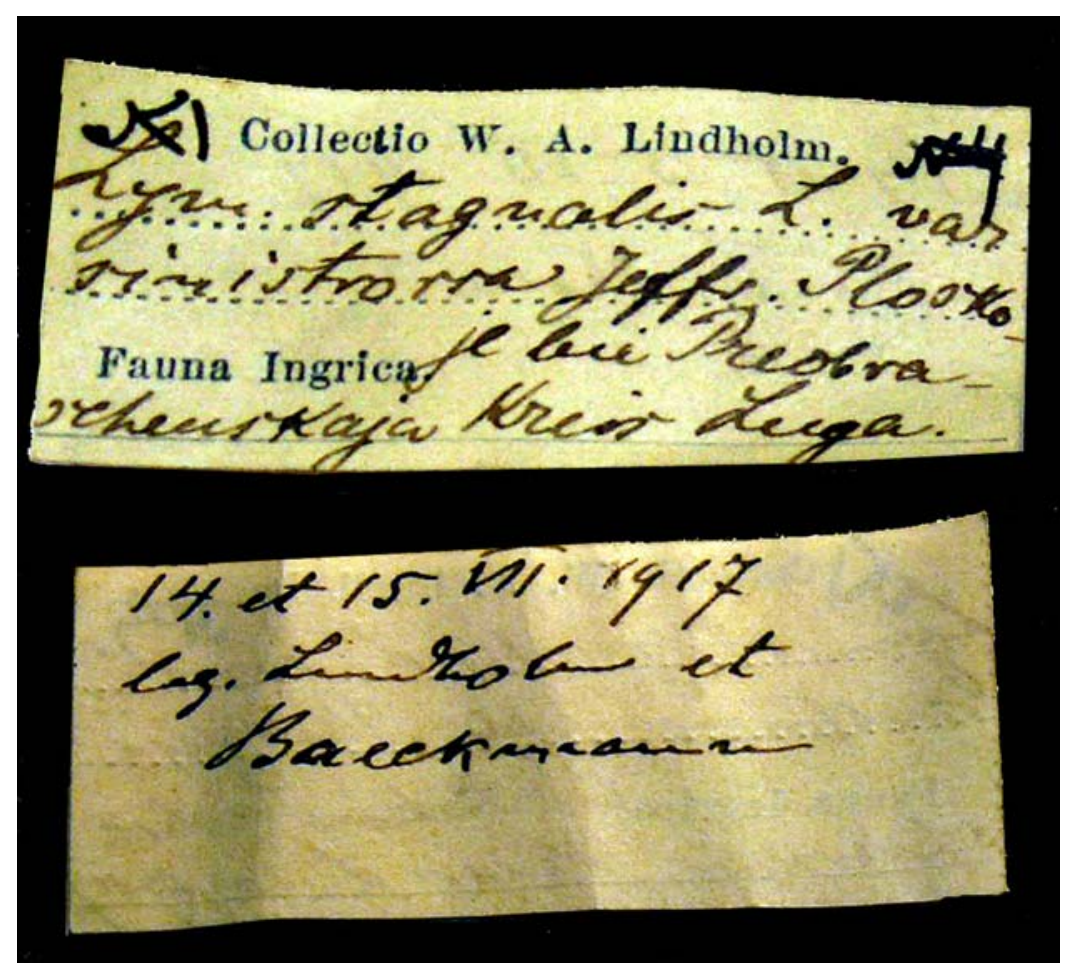

Fig. 2. The original label attached to the box containing Lymnaea stagnalis var. sinistrorsa.

The formation of predominantly sinistral population of the Ploskoje Lake may be due to a few or a single individual of $L$. stagnalis having a "left-handed" maternal genotype. This animal could be the founder of the population, and it is not known, whether it was dextral in somatic appearance, or sinistral. All the offspring of this founder had left-handed shells and dextral specimens might originated in subsequent generations by means of the genetical mechanisms, described in detail by FREEMAN \& Lundelius (1982). By this way, di- morphic population of $L$. stagnalis may arise. Of course, sampling bias can not be excluded since may has been occurred since Lindholm and Bäckmann might have collected mainly sinistral shells. I consider this alternative unlikely since I believe that W.A. Lindholm, having been a thoughtful malacologist, was interested in learning of an exact proportion of sinistral and dextral shells in the lake, therefore his sample should reflect the true ratio between the two phenotypes.

Table 1. Morphometric characteristics of sinistral individuals of Lymnaea stagnalis $(\mathrm{n}=14)$ from the Ploskoje Lake (Preobrazhenskoje, Leningrad Region, Russia).

\begin{tabular}{|l|c|c|}
\hline Shell character & Minimum - maximum & Mean \pm SE \\
\hline Whorl number & $5.50-6.87$ & $6.24 \pm 0.13$ \\
\hline Shell heigth (SH), mm & $25.1-45.1$ & $34.0 \pm 1.6$ \\
\hline Shell width (SW), mm & $10.8-23.2$ & $16.7 \pm 1.1$ \\
\hline Spire heigth (SpH), mm & $14.9-22.6$ & $18.0 \pm 0.7$ \\
\hline Body whorl heigth (BWH), mm & $18.4-34.3$ & $25.1 \pm 1.3$ \\
\hline Aperture heigth (AH), mm & $12.3-26.1$ & $18.7 \pm 1.1$ \\
\hline Aperture width (AW), mm & $7.2-16.4$ & $11.1 \pm 0.7$ \\
\hline SW/SH & $0.43-0.54$ & $0.47 \pm 0.01$ \\
\hline SpH/SH & $0.46-0.57$ & $0.52 \pm 0.01$ \\
\hline BWH/SH & $0.71-0.77$ & $0.74 \pm 0.005$ \\
\hline AH/SH & $0.49-0.60$ & $0.55 \pm 0.01$ \\
\hline AW/SH & $0.53-0.64$ & $0.59 \pm 0.01$ \\
\hline AW/AH & $0.29-0.37$ & $0.32 \pm 0.01$ \\
\hline
\end{tabular}




\section{Conclusion}

SCHILTHUIZEN \& DAVISON (2005) assume that dimorphic populations of snails will not persist for a long time because of difficulty finding a suitable mating partner. The high ratio of shells with opposite coiling in the Ploskoje Lake population would indicate that there may be mechanisms (most probably, behavioural) that prevent mixed populations of Lymnaea from disappearance.

A most interesting study would be a repeated examination of the Ploskoje Lake population of L. stagnalis. I hope that someone of Sankt-Petersburg malacologists is able to find this locality to extend W.A. Lindholm's study. However, there seem not so many chances to do it. The main cause of it is that since 1917 the habitat may have been altered or destroyed completely with eventual extinction of this interesting dimorphic population of L. stagnalis.

\section{Acknowledgements}

I am greatly indebted to Pavel V. Kijashko, Lidia L. Yarochnovich (Sankt-Petersburg, Russia) and Maxim E. Grebennikov (Yekaterinburg, Russia) for their kind assistance during my work with the collection of the Zoological Institute of RAS. I acknowledge I.M. Khokhutkin (Yekaterinburg, Russia). who made his rich malacological library available to me as well as Peter Glöer (Hetlingen, Germany) and Michal Novák (Prague, Czech Republic) for debates on some topics discussed in the paper. Advise of an anonymous referee has resulted in a significant improvement of the final text.

\section{References}

Aleksandrov D.A. \& Sergievsky S.O., 1979: Об одном варианте симпатрического видообразования у брюхоногих моллюсков [One variant of sympatric speciation in snails]. - In: Molluses, main results of their study, LIKHAREV I.M. (ed.) Sixth meeting on the investigation of molluscs. Theses of communications. Nauka, Leningrad, 153-154 (in Russian).

ANISTRATENKO V.V. \& BAIDASHNIKOV A.A., 1991: Эволюционное значение инверсии завитости раковин у моллюсков [Evolutionary significance of shell coiling inversions in molluscs]. - Vestnik zoologii, 2: 10-14 (in Russian).

AsAmi T., CowiE R.H. \& OHBAYASHI K., 1998: Evolution of mirror images by sexually asymmetric mating behaviour in hermaphroditic snails. - The American Naturalist, 152: 225236.

BoycotT A.E. \& Diver C., 1923: On the inheritance of sinistrality in Limnaea peregra. - Proceedings of the Royal Society of London, B 95: 207-213.

BoycotT A.E. \& Diver C., 1930: Abnormal forms of Limnaea peregra obtained in artificial breeding and their inheritance. - Proceedings of the Malacological Society, London, 19: 141-146.

Boycott A.E., Diver C., Gartang A.C. \& Turner F.M., 1930: The inheritance of sinistrality in Lymnaea peregra (Mollusca, Pulmonata). - Philosophical Transactions of the Royal Society of London, B 219: 51-131.

Davison A., Chiba S., Barton N.H. \& Clarke B., 2005: Speciation and gene flow between snails of opposite chirality.-PloS Biology, 3: 282.
DIVER, C. \& ANDERSON-KotTÖ J., 1938: Sinistrality in Limnaea peregra (Mollusca: Pulmonata): the problem of mixed broods. - Journal of Genetics, 3: 447-525.

FREEMAN G. \& LUNDELIUS J.W., 1982: The developmental genetics of dextrality and sinistrality in the gastropod Lymnaea peregra. - Wilhelm Roux' Archives, 191: 69-83.

GitTENBERGER E., 1988: Sympatric speciation in snails: A largely neglected model. - Evolution, 42: 826-828.

GlÖER P., 2002: Die Süßwassergastropoden Nord- und Mitteleuropas. - Die Tierwelt Deutschlands, 73. Conchbooks, Hackenheim. 327 pp.

Gould S.J., Young N.D. \& Kasson B., 1985: The consequences of being different: Sinistral coiling in Cerion. - Evolution, 39: 1364-1379.

HuBENDICK B., 1951: Recent Lymnaeidae. Their variation, morphology, taxanomy, nomenclature and distribution. Kunglige Svenska Vetenskapsakademiens Handlingar, series 4 3: $1-223$.

InODA T., Hirata Y. \& Kamimura S., 2003: Asymmetric mandibles of water-scavenger larvae improve feeding effectiveness on right-handed snails. - The American Naturalist, 162: 811-814.

JACKIEWICZ M., 1998: European species of the family Lymnaeidae (Gastropoda, Pulmonata, Basommatophora). Genus, 9: 1-93.

JOHNSON M.S., 1982: Polymorphism for direction of coil in Partula suturalis: Behavioural isolation and positive frequency dependent selection. - Heredity, 49: 145-151.

JoHNSON M.S., 1987: Adaptation and rules of form: chirality and shape in Partula suturalis. - Evolution, 41: 672-675.

Johnson M.S., Clarke B. \& Murray J., 1990. The coil polymorphism in Partula suturalis does not favour sympatric speciation. - Evolution, 44: 459-464.

KHOKHUTKIN I.M., 1997: Структура изменчивости видов на примере наземных моллюсков [The structure of species' variability as illustrated by terrestrial snails]. Uralian Branch of the Russian Academy of Science, Yekaterinburg, 176 pp. (in Russian).

KRUGLOV N.D., 2005: Моллюски семейства прудовиков (Lymnaeidae: Gastropoda: Pulmonata) Европы и Северной Азии [Molluscs of the family Lymnaeidae of Europe and Northern Asia]. - Smolensk State Pedagogical University Press, Smolensk. 507 pp. (in Russian).

KRUGLOV N.D. \& StaRobogatov YA.I., 1985: Methods of experimental hybridization and some results of its applications in the taxonomy of Lymnaeidae. Malacological Review, 18: 21-35.

MAYR E., 1963. Animal species and evolution. - Harvard University Press, Harvard (Massachusets), 797 pp.

MeIER-BrooK C., 1993: Artaufassungen in Bereich der limnischen Mollusken und ihr Wahd im 20 Jahrhundert. Archiv für Molluskenkunde, 122: 133-147.

SCHilthuizen M. \& DAVISON A. 2005. The convuluted evolution of snail chirality. - Naturwissenschaften, 92: 504515.

STADNICHENKO A.P., 2004: Прудовиковые и чашечковые Украины [Lymnaeidae and Acroloxidae of Ukraine]. Centr Uchebnoj Literatury, Kiev. 327 pp. (in Russian).

StuRTEVANT A.H., 1923: Inheritance of direction of coiling in Limnaea. - Science, New Series, 58: 269-270.

Ueshima R. \& Asami T., 2003: Single-gene speciation by left-right reversal. - Nature, 425: 679.

VERMEIJ G.J., 1975: Evolution and distribution of lefthanded and planispiral coiling in snails. - Nature, 254: 419420. 
VINARSKI M.V., ANDREEV N.I. \& KARIMOV A.V., 2007: Широтная изменчивость размеров пресноводных легочных моллюсков (Mollusca: Gastropoda: Pulmonata) в Запа- дной Сибири [Latitudinal variation of body sizes in Western Siberian freshwater snails (Mollusca: Gastropoda: Pulmonata)]. - Ekologija (in press). (in Russian). 